\title{
Taking a stand against illegal wildlife trade: the Zimbabwean approach to pangolin conservation
}

\author{
Chris R. Shepherd, Ellen Connelly, Lisa Hywood and Phillip Cassey
}

\begin{abstract}
Pangolins are increasingly threatened by demand for their scales, which are used in traditional medicines, and for their meat, which is consumed as a luxury. As populations of Asian pangolins decline, the demand is shifting to the four species in Africa, where local cultural use may already pose some level of threat. During 2010-2015 a total of 65 pangolin-related seizures (surrendered and confiscated) were reported in Zimbabwe, with the annual number of confiscations increasing significantly over this period. Zimbabwean authorities have toughened their stance against this trade, and during January-June 2015 threequarters of confiscations of pangolins $(n=12)$ resulted in the maximum jail sentence for at least one of the offenders in each case. At present there is no evidence that pangolins are being traded from Zimbabwe to China, and the increased enforcement may be key to ensuring Zimbabwe's pangolins are not threatened by the large-scale illegal trade witnessed in Asia.
\end{abstract}

Keywords Illegal trade, species conservation, Smutsia temminckii, Temminck's ground pangolin, transnational biosecurity, wildlife trafficking

To view supplementary material for this article, please visit http://dx.doi.org/10.1017/So03060531600o119

\section{Introduction}

7 he global trade in wildlife is estimated to be worth bil1 lions of dollars and to involve hundreds of millions of specimens every year (Broad et al., 2003; Smith et al., 2009; Rosen \& Smith, 2010). The trade is diverse, ranging from live animals to a vast array of wildlife products, curiosities and derivatives (Broad et al., 2003; Lee et al., 2014). Both legal and illegal wildlife traders are adaptable to changing circumstances (TRAFFIC, 2008), with both groups targeting new species when others become depleted, and, in the case of illegal trade, developing new smuggling methods

Chris R. SHEPHERd (Corresponding author) TRAFFIC Southeast Asia, Unit 3-2, 1st Floor, Jalan SS23/11, Taman SEA, 47400 Petaling Jaya, Selangor, Malaysia E-mail chris.shepherd@traffic.org

Ellen Connelly and Lisa Hywood The Tikki Hywood Foundation, Harare, Zimbabwe

Phillip CASSEY School of Biological Sciences and the Environment Institute, University of Adelaide, Adelaide, Australia

Received 25 November 2015. Revision requested 22 December 2015. Accepted 19 January 2016. First published online 27 April 2016. and transportation routes to avoid detection (South \& Wyatt, 2011; Wyatt, 2013; Challender et al., 2015a). Here, we consider the case of the African pangolins (Pholidota: Manidae), which are potentially under increasing threat from demand in Asia (Pietersen et al., 2014b). The illegal trade in pangolins is most conspicuous in China (Shepherd, 2009; Challender et al., 2015b), where their meat is considered a luxury food and their scales are used in traditional medicines (Wu et al., 2004).

Pangolins are small- to medium-sized insectivorous mammals, with unique scaled armour covering the body and tail (Gaudin et al., 2009). All eight species are highly sought after, and the greatest threat to their survival is the illegal trade to supply the Chinese traditional medicine market, and meat for consumption (Challender et al., 2014c; Nijman, 2015; Nijman et al., 2016). The four Asian pangolin species have been the most affected thus far (Challender, 2011; Challender et al., 2015a), with shipments in the tens of tonnes being smuggled from South-east Asian range countries to China (Shepherd, 2009; Challender et al., 2012). As a result of the illicit wildlife trade, two of the four Asian species are now categorized as Critically Endangered on the IUCN Red List of Threatened Species (Challender et al., 2014a,b), and two as Endangered (Baillie et al., 2014; Lagrada et al., 2014). With populations of all four of these species in decline, the trade has shifted to Africa (Challender \& Hywood, 2012), where until recently, large-volume shipments to China were virtually unrecorded (but see Table 1). The four African pangolin species are categorized as Vulnerable (Pietersen et al., 2014a; Waterman et al., 2014a,b,c) but the increasing demand in local markets (Soewu \& Sodeinde, 2015) and the apparently rapid growth in demand from Asia (Challender \& Hywood, 2012; Zhou et al., 2014) indicate that these assessments may need to be revised.

All eight pangolin species are listed in Appendix II of CITES (2015a), which requires the exporting country to issue permits for legal international trade. There is currently a zero trade quota for wild-caught individuals of the four Asian species, and international commercial trade in wildcaught individuals of these species is strictly prohibited. However, no quotas (zero or otherwise) have been established for the four African species. Trade in the African species is allowed if permitted under the national laws of the countries involved, and if in accordance with CITES regulations. Zimbabwe became a Party to CITES in 1981, and therefore any international trade must be conducted with explicit permission and accompanied by the necessary approval documents from the Government of Zimbabwe. 
TABLE 1 Seizures of pangolin parts en route from Africa to Asia during January-June 2015 (Guo Yanyan, TRAFFIC East Asia, unpubl. data), with date and location of seizure, country of origin, items seized, species, and quantity.

\begin{tabular}{|c|c|c|c|c|c|}
\hline Date & Location of seizure & Country of origin* & Items seized & Species & Quantity (kg) \\
\hline 26 Jan. & Entebbe Airport, Uganda & Uganda & Skins & Not reported & 2,000 \\
\hline 10 Feb. & $\begin{array}{l}\text { Yengo, Brazzaville, } \\
\text { Republic of the Congo }\end{array}$ & Republic of the Congo & Scales & Not reported & 150 \\
\hline 17 Feb. & Hong Kong & Kenya & Scales & $\begin{array}{l}\text { Temminck's ground pangolin } \\
\text { Smutsia temminckii }\end{array}$ & 1,000 \\
\hline 20 Feb. & Hong Kong & Kenya & Scales & Temminck's ground pangolin & 2,500 \\
\hline 20 Mar. & Hong Kong & Nigeria & Scales & Not reported & 2,000 \\
\hline 18 May & Shanghai Airport, China & $\begin{array}{l}\text { Africa (country } \\
\text { not reported) }\end{array}$ & Scales & Not reported & 249 \\
\hline
\end{tabular}

${ }^{*}$ None of these shipments originated in Zimbabwe.

Prior to 2013, to the best of our knowledge, there were no recorded pangolin shipments from Africa to Asia exceeding $500 \mathrm{~kg}$. Since then, trade from Africa to Asia has escalated. In the first 6 months of 2015 alone c. $8 \mathrm{t}$ of skins and scales were seized en route from Congo, Kenya, Nigeria and Uganda to Asia, with four of the six seizures reportedly $\geq 500$ $\mathrm{kg}$ (Table 1). None of these shipments, however, involved Zimbabwe.

Temminck's ground pangolin Smutsia temminckii is the only species of pangolin native to Zimbabwe (Gaudin et al., 2009; Gaubert, 2011), and in 1975 it was placed on Zimbabwe's Specially Protected Species list, which affords the species full protection. According to the Zimbabwean Parks and Wildlife Act (Chapter 20:14) Section 128 Special Penalty for Certain Offences, under the General Laws Amendment No. 5 (G. N. 148/2011), any person that is convicted of the unlawful killing, possession of, or trading in any Specially Protected Species is liable, on first conviction, to imprisonment for a period of not less than 9 years, and for a second or subsequent conviction to imprisonment for a period of not less than 11 years. Alternatively, if the convicted person satisfies the court that there are special circumstances justifying the imposition of a lesser penalty (the particular facts of which are recorded by the court), the convicted person is liable to a fine four times the value of the specimen. The current value for an individual pangolin (USD 5,000) was set in 2012 and was based on an assessment of the asking price for a Temminck's ground pangolin at that time.

Little is known of the status of Temminck's ground pangolin, and there is a lack of empirical data on populations (e.g. Pietersen et al., 2014a). Wild populations are thought to be in decline (Pietersen et al., 2014a,b), with threats including electrocution on electrified fences, habitat loss, road mortalities, and capture in gin traps. Hunting for bushmeat and local use in traditional medicine (muthi) is also a threat (Bräutigam et al., 1994; Soewu \& Sodeinde, 2015). However, if unchecked, demand from East Asia for use in traditional medicines and for food may increasingly become the most significant threat (Challender \& Hywood, 2012). It has been recommended that trade levels and routes should be monitored closely to determine the extent of this trade and the volume of pangolins being traded (Pietersen et al., 2014b).

Wildlife poaching and illegal wildlife trade have generated massive problems for species conservation in Zimbabwe (Warchol, 2004). To date, the majority of wildlife-related prosecutions in Zimbabwe have focused on crimes relating to poaching of the African elephant Loxodonta africana and the white Ceratotherium simum and black rhinoceros Diceros bicornis. The national enforcement agencies have now included pangolin-related crime as a serious wildlife offence. Here, we quantify the increase and distribution in illegal trade in Temminck's ground pangolin (hereafter referred to as pangolin) detected in Zimbabwe during October 2010-June 2015. We also evaluate the measures taken to suppress this illegal trade, through seizures, prosecution penalties, and convictions by the Zimbabwe Parks and Wildlife Management Authority, magistrates and public prosecutors in Zimbabwe.

\section{Methods}

Pangolin seizure data were compiled from information provided directly by the Zimbabwe Parks and Wildlife Management Authority and the Tikki Hywood Trust. In addition, we monitored all pangolin-related cases in Zimbabwean courts, as well as media information and press releases. Information on seizures in China of pangolins or pangolin derivatives originating from Zimbabwe was collated from records requested through the Wildlife Trade Monitoring Network (TRAFFIC) and the CITES Trade Database (CITES, 2015b). All records of trade involving Zimbabwe as an exporting country of pangolins were included; the databases were last queried in July 2015.

For each case involving seizures of pangolins or pangolin parts in Zimbabwe we collected the following information: 
(1) date of seizure; (2) type of seizure (surrendered or confiscated); (3) number of pangolins involved; (4) condition of the pangolins (live, dead, body parts); (5) nationality of the offender; (6) location of the seizure; (7) agencies involved in making the seizure; and (8) resulting penalties handed down to the offender(s).

Data were collected between October 2010 and the end of June 2015. Prior to $2010<5$ pangolins were seized in Zimbabwe (Pietersen et al., 2014b). Information regarding these early cases was not formally recorded by the authorities and therefore was not included in the analysis. Since October 2010, seizures in Zimbabwe have been conducted by the Zimbabwe Parks and Wildlife Management Authority, Zimbabwe Republic Police, and the Mineral Section of the Central Intelligence Organisation, and details of all pangolin seizures were recorded. Despite the quality of our data, we acknowledge that they cannot be interpreted as absolute numbers (or frequency) of illegal trade, because they do not account for the law enforcement effort during the study period (Challender et al., 2015a).

All data analyses were conducted in $R \quad v$. 3.2 .2 (R Development Core Team, 2015). We fitted generalized linear models to test for (1) the relative change in the number of detections (seized and surrendered) through time (Poisson error distribution and log link function); (2) the relative change in the proportion of seizures from the capital city, Harare, compared with other localities (binomial error distribution and logit link function); and (3) the increase in the jail term (months) imposed following successful prosecution through time (Poisson error distribution and log link function).

\section{Results}

During the period from October 2010 until the end of June 2015 there were a total of 65 pangolin seizures reported in Zimbabwe (Supplementary Table $S_{1}$ ). During the same period there were no recorded seizures in China of pangolins that originated in Zimbabwe, although there were seizures of pangolins originating from other African countries (Table 1). The number of pangolins confiscated increased significantly during the study period (estimate [log-link scale $] \pm \mathrm{SE}=0.71 \pm 0.13, Z=5.30, \mathrm{P}<0.001)$ but the number of pangolins surrendered did not $(0.20 \pm 0.16, Z=1.27$, $\mathrm{P}=0.203$; Fig. 1).

Of the 65 seizures , 58 ( $89 \%)$ involved live pangolins and nine involved dead pangolins, including one seizure of skins and scales. Almost two-thirds of all known seizures (confiscated and surrendered) went through Harare (annual mean $=65.6 \%$ (95\% CI 44-98); Fig. 2a). The proportion of seizures of Temminck's ground pangolin occurring in Harare has not changed significantly through time (estimate [logit-link scale] $\pm \mathrm{SE}=-0.47 \pm 0.28, Z=-1.66, \mathrm{P}=0.096$ ).
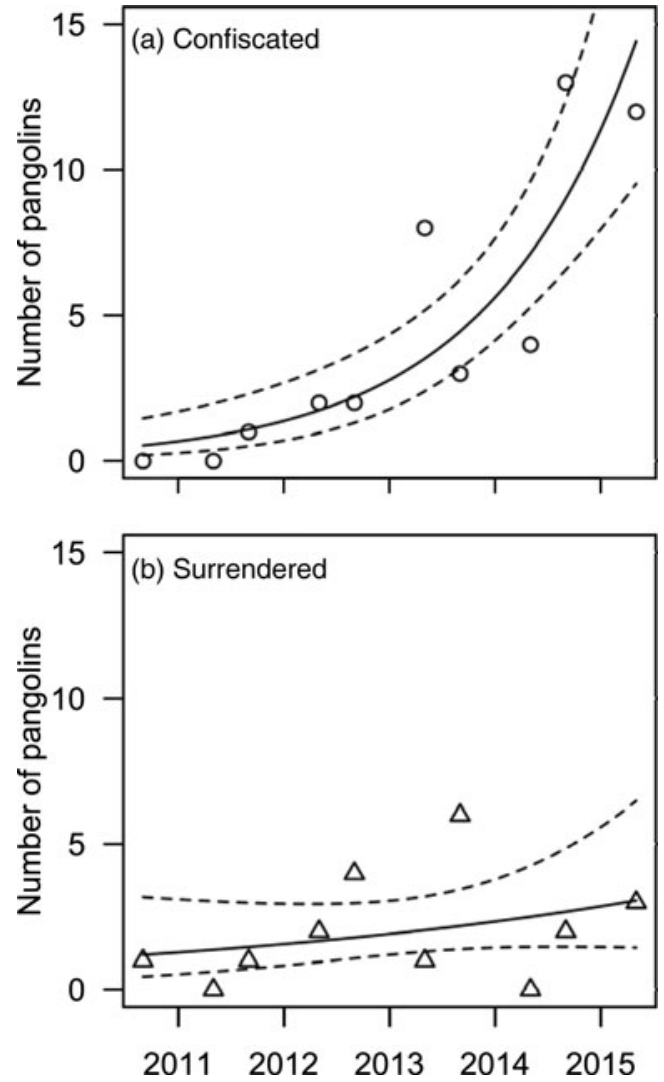

FIG. 1 The number of Temminck's ground pangolins Smutsia temminckii (a) confiscated or (b) surrendered during 2010-2015, in 6-monthly intervals (January-June and July-December); $\mathrm{n}=65$.

The location with the next highest seizure rate was the rural town of Gokwe Centre (7.7\%).

A total of 89 suspects were apprehended, involving 39 confiscation incidents with data. Two-thirds of these confiscations ( 26 of $39 ; 67 \%$ ) involved the apprehension of two or more offenders. The mean number of people apprehended in conjunction with the confiscation of pangolins was $2.28 \pm$ SE 0.23; the maximum number reported for a single incident was seven. In the majority of confiscations (34 of 39; $87.2 \%$ ) an offender was either fined (USD $822 \pm$ SE 530 ) or received a jail term. The length of jail terms has increased significantly through time (o.68 $\pm \mathrm{SE} 0.12$ years, $Z=5.55$, $\mathrm{P}<$ 0.001; Fig. 2 b), and in January-June $201575 \%$ of pangolin confiscations $(n=12)$ resulted in a penalty of 9 years in jail for at least one offender.

Almost one-third of incidents ( 20 of $65 ; 31 \%$ ) were not treated as criminal offences. In four of these cases the pangolins were intended as cultural gifts to authorities. In a further 11 cases the pangolins were retrieved from people who had reported them in their gardens, although some of these were presumed to have escaped from poachers (one had a nylon snare around its neck) and most were found in areas where pangolins were unlikely to occur naturally. In a further five cases the origin of the pangolin was unknown. 

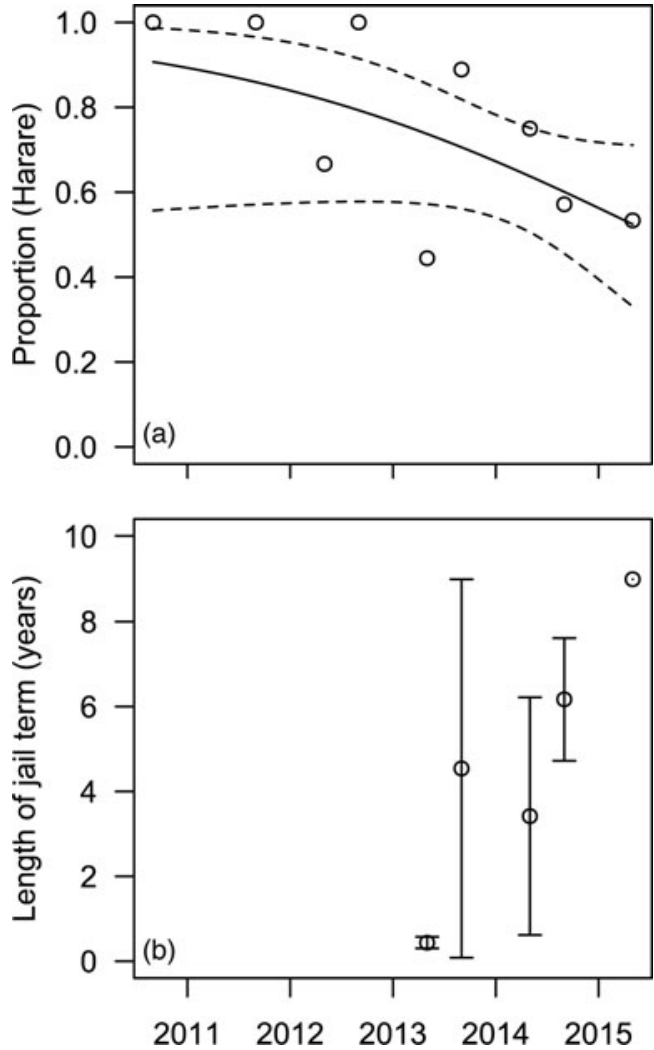

FIG. 2 (a) The proportion of seizures of Temminck's ground pangolins from the Zimbabwean capital city of Harare during 2011-2015. The fitted line is from a generalized linear model with binomial error function and logit link function; the dotted lines are $95 \%$ confidence intervals. (b) The jail terms $( \pm$ SE) imposed following seizures of Temminck's ground pangolins in Zimbabwe during 2010-2015, in 6-monthly intervals (January-June and July-December).

Of the offenders who have been prosecuted, all except two Mozambicans and two Zambians are Zimbabwean nationals. All of the pangolins confiscated or surrendered were sourced locally from Zimbabwe, with the exception of one that was seized while being smuggled into the country from Mozambique in 2012. The offender was a Mozambican, who was subsequently deported without further penalty.

Of the 53 live pangolins that were seized, 32 (60\%) were released back into the wild. All were given a health check and, if deemed fit, were released into protected areas, including national parks, as close to the area of capture as possible, if known. Of the remaining 21, 16 died and five were kept in captive care because they were in poor condition or were too young to be released successfully at the time of seizure.

\section{Discussion}

In Zimbabwe pangolins have been collected from the wild for bushmeat and cultural use, including traditional medicine (Pietersen et al., 2014b; Soewu \& Sodeinde, 2015).
According to cultural beliefs, pangolins are intricately entwined with the spiritual realm and with the protection and well-being of the people and their villages (Anchors, 2002). However, the recorded value of a live pangolin in Zimbabwe has increased 25-fold in just 5 years (20072012). During the study period all individuals who were prosecuted for pangolin-related offences in Zimbabwe were arrested in the act of trying to sell the pangolins for commercial gain and were clearly not in possession of the pangolins for the purposes of traditional cultural beliefs.

During 2000-2012 conviction rates for offenders involved in pangolin-related crimes were low. At that time the national judicial system was unaware of the emerging illegal trade in pangolins, the potential threat to their conservation, and their Specially Protected Species status. Public prosecutors were inexperienced in processing pangolinrelated crimes (Lisa Hywood, pers. obs.). In 2013 a handbook for evaluating and prosecuting wildlife crimes in Zimbabwe was produced, and was distributed to all magistrates and public prosecutors throughout Zimbabwe, detailing how pangolin-related cases should be handled and which penalties were appropriate, considering the financial value of pangolins on the black market (Hywood \& Connelly, 2013).

The largest reported seizure in Zimbabwe to date involved two pangolins, although during 1 week in April 2015 there were nine separate cases involving nine individual pangolins. These volumes are in stark contrast with seizures in Indonesia and Vietnam, which sometimes exceed $10 \mathrm{t}$ per seizure (Shepherd, 2009), or volumes for sale in Asian wet markets (Nijman et al., 2016). Seizures of pangolin parts originating from Africa (excluding Zimbabwe) during January-June 2015 averaged $1.3 \pm$ SE $0.41 \mathrm{t}$ (skins and scales; Table 1). Although it may be argued that larger shipments of pangolins from Zimbabwe may be taking place undetected, we believe this is unlikely, as surveys and informants do not indicate any large-scale harvest is taking place. Informants in Zimbabwe have indicated that the fear of law enforcement activities and strong penalties are a deterrent.

It is premature to assume that the penalties associated with pangolin-related crimes (e.g. a 9-year jail term) are suppressing the illegal export of pangolins from Zimbabwe; however the small numbers of pangolins observed in trade, the consistent surrendering of pangolins that could otherwise provide supplementary income in a country with one of the lowest gross domestic products per capita (c. USD 2,000 per year; CIA, 2015), and the widespread awareness of the severity of penalties are suggestive of a strong deterrent. More research into the economic values along the trade chain in Zimbabwe is required to estimate the mean value (and variability) of asking prices for pangolins. We recommend and encourage further collection and analysis of prices of pangolins, and other African species in illegal wildlife trade generally. 
No one arrested for pangolin-related crimes in Zimbabwe has suggested that Zimbabwean pangolins are being sold to China or are being purchased by buyers from Asia. In two cases, both in 2015, the sellers stated to the arresting officers that they were selling pangolins to the local Indian community for ritual purposes. However, at this time we have no further information regarding these rituals. With pangolins already being depleted throughout much of their range in Asia, a strong stand against the domestic trade is perhaps the most effective method to ensure the pangolin populations in Africa are not also lost through increasing international export (e.g. Challender et al., 2015a). Continual monitoring of the trade and enforcement efforts in Zimbabwe, and the related demand levels in China, is key to understanding better the relationship between effective enforcement (including stiff penalties) and positive conservation results. Such studies should be replicated in other countries, and successful enforcement actions reproduced elsewhere where pangolins (and other species) are threatened by intense demand (Challender \& MacMillan, 2014). It is necessary to raise awareness of the illegality of the pangolin trade, and the resulting penalties, to deter more people from becoming involved in the trade and to prevent African nations from losing their pangolins.

The evidence that pangolins were surrendered voluntarily is encouraging, as this too may signify an awareness of the laws and of the penalties for trading in pangolins. However, the number of confiscations is increasing. It may be useful in the future to conduct an assessment of awareness amongst the public of the laws pertaining to pangolins in Zimbabwe, to guide potential awareness-raising efforts (Challender \& MacMillan, 2014). Although the number of pangolin-related crimes (confiscations and prosecutions) has increased in Zimbabwe, we believe that the strong response from the Zimbabwean authorities has resulted in a relatively low number of attempts to sell pangolins, and a low number of pangolins being taken from the wild to supply the black market demand (Schneider, 2008); for example, there have been no incidents involving more than two individual pangolins, and continual monitoring of the trade will provide further confirmation or otherwise. Dedicated monitoring of the trade by an NGO (Tikki Hywood Foundation), and close collaboration with authorities, has proven to be an effective approach to combating the illegal trade in pangolins in Zimbabwe. The collection of information pertaining to pangolin-related crimes should be conducted at a national level, with a centralized database for analysis of the illegal trade, to monitor and support conservation and enforcement efforts (Challender et al., 2015b). We strongly recommend that the approach taken in Zimbabwe is replicated in other African pangolin range countries to avert a potential pangolin trade crisis similar to that involving Asian pangolins, and to further deter the international trade.

\section{Acknowledgements}

PC was an Australian Research Council (ARC) Future Fellow (FTo91442O) at the time of this work, which was supported by an ARC Discovery Grant (DP140102319). CRS thanks David Newton and Roland Melisch for their comments.

\section{References}

AnCHORs, J.C. (2002) Zimbabwean land and Zimbabwean people: creative explorations. MA thesis. The University of Maine, Orono, USA.

Baillie, J., Challender, D., Kaspal, P., Khatiwada, A., Mohapatra, R. \& Nash, H. (2014) Manis crassicaudata. The IUCN Red List of Threatened Species 2014: e.T12761A45221874 [accessed 8 January 2016].

Bräutigam, A., Howes, J., Humphreys, T. \& Hutton, J. (1994) Recent information on the status and utilization of African pangolins. TRAFFIC Bulletin, 15, 15-22.

Broad, S., Mulliken, T. \& Roe, D. (2003) The nature and extent of legal and illegal trade in wildlife. In The Trade in Wildlife: Regulation for Conservation (ed. S. Oldfield), pp. 3-22. Earthscan, London, UK.

Challender, D. (2011) Asian pangolins: increasing affluence driving hunting pressure. TRAFFIC Bulletin, 23, 92-93.

Challender, D., Baillie, J., Ades, G., Kaspal, P., Chan, B., Khatiwada, A. et al. (2014a) Manis pentadactyla. The IUCN Red List of Threatened Species 2014: e.T12764A45222544 [accessed 8 January 2016].

Challender, D., Baillie, J.E.M., Waterman, C. \& the IUCN-SSC Pangolin Specialist Group (2012) Catalysing conservation action and raising the profile of pangolins - the IUCN-SSC Pangolin Specialist Group (PangolinSG). Asian Journal of Conservation Biology, 1, 140-141.

Challender, D., Harrop, S.R. \& MacMillan, D.C. (2015a) Understanding markets to conserve trade-threatened species in CITES. Biological Conservation, 187, 249-259.

Challender, D., Harrop, S.R. \& MacMillan, D.C. (2015b) Towards informed and multi-faceted wildlife trade interventions. Global Ecology and Conservation, 3, 129-148.

Challender, D. \& Hywood, L. (2012) African pangolins under increased pressure from poaching and intercontinental trade. TRAFFIC Bulletin, 24, 53-55.

Challender, D. \& MacMillan, D.C. (2014) Poaching is more than an enforcement problem. Conservation Letters, 7, 484-494.

Challender, D., Nguyen Van, T., Shepherd, C., Krishnasamy, K., WAnG, A., LeE, B. et al. (2014b) Manis javanica. The IUCN Red List of Threatened Species 2014: e.T12763A45222303 [accessed 8 January 2016].

Challender, D., Waterman, C. \& Baillie, J.E.M. (2014c) Scaling Up Pangolin Conservation. IUCN SSC Pangolin Specialist Group Conservation Action Plan. Zoological Society of London, London, UK.

CiA (Central Intelligence Agency) (2015) The World Factbook. Https://www.cia.gov/library/publications/resources/the-worldfactbook/geos/zi.html [accessed 15 July 2015].

CITES (2015a) The CITES Appendices. Http://www.cites.org/eng/app/ index.shtml [accessed 18 March 2016].

CITES (2015b) CITES Trade Database. Http://trade.cites.org/ [accessed 18 March 2016].

Gaubert, P. (2011) Family Manidae. In Handbook of the Mammals of the World: Hoofed Mammals 2 (eds D.E. Wilson \& R.A. Mittermeier), pp. 82-103. Lynx Edicions, Barcelona, Spain. 
GAUdin, T.J., Emry, R.J. \& WibLE, J.R. (2009) The phylogeny of living and extinct pangolins (Mammalia, Pholidota) and associated taxa: a morphology based analysis. Journal of Mammalian Evolution, 16, 235-305.

Hywood, L. \& Connelly, E. (2013) Handbook for Evaluating and Prosecuting Wildlife Crimes in Zimbabwe. Tikki Hywood Foundation, Harare, Zimbabwe.

Lagrada, L., Schoppe, S. \& Challender, D. (2014) Manis culionensis. The IUCN Red List of Threatened Species 2014: e.T136497A45223365 [accessed 8 January 2016].

Lee, T.M., Sigouin, A., Pinedo-Vasquez, M. \& Nasi, R. (2014) The harvest of wildlife for bushmeat and traditional medicine in East, South and Southeast Asia: Current knowledge base, challenges, opportunities and areas for future research. Occasional Paper 115. CIFOR, Bogor, Indonesia.

Nijman, V. (2015) Pangolin seizures data reported in the Indonesian media. TRAFFIC Bulletin, 27, 44-46.

Nijman, V., Zhang, M.X. \& Shepherd, C.R. (2016) Pangolin trade in the Mong La wildlife market and the role of Myanmar in the smuggling of pangolins into China. Global Ecology and Conservation, 5, 118-126.

Pietersen, D., Waterman, C., Hywood, L., Rankin, P. \& Soewu, D (2014a) Smutsia temminckii. The IUCN Red List of Threatened Species 2014: e.T12765A45222717 [accessed 8 January 2016].

Pietersen, D.W., McKechnie, A.E. \& Jansen, R. (2014b) A review of the anthropogenic threats faced by Temminck's ground pangolin, Smutsia temminckii, in southern Africa. South African Journal of Wildlife Research, 44, 167-178.

R Development Core Team (2015) R: A Language and Environment for Statistical Computing. R Foundation for Statistical Computing, Vienna, Austria.

Rosen, G.E. \& S Sith, K.F. (2010) Summarizing the evidence on the international trade in illegal wildlife. EcoHealth, 7, 24-32.

SCHNEIDER, J.L. (2008) Reducing the illicit trade in endangered wildlife: the market reduction approach. Journal of Contemporary Criminal Justice, 24, 274-295.

Shepherd, C.R. (2009) Overview of pangolin trade in Southeast Asia. In Proceedings of the Workshop on Trade and Conservation of Pangolins Native to South and Southeast Asia, 30 June-2 July, 2008, Singapore Zoo, Singapore (eds S. Pantel \& S. Y. Chin), pp. 6-9. TRAFFIC Southeast Asia, Petaling Jaya, Selangor, Malaysia.

Smith, K.F., Behrens, M., Schloegel, L.M., Marano, N., Burgiel, S. \& DASZAK, P. (2009) Reducing the risks of the wildlife trade. Science, 324, 594-595.
Soewu, D.A. \& Sodeinde, O.A. (2015) Utilization of pangolins in Africa: fuelling factors, diversity of uses and sustainability. International Journal of Biodiversity and Conservation, 7, 1-10.

South, N. \& Wyatт, T. (2011) Comparing illicit trades in wildlife and drugs: an exploratory study. Deviant Behavior, 32, 538-561.

TRAFFIC (undated) Http://www.traffic.org [accessed 18 March 2016].

TRAFFIC (2008) What's Driving the Wildlife Trade? A Review of Expert Opinion on Economic and Social Drivers of the Wildlife Trade and Trade Control Efforts in Cambodia, Indonesia, Lao PDR and Vietnam. East Asia and Pacific Region Sustainable Development Discussion Papers, World Bank, Washington, DC, USA.

WARCHOL, G.L. (2004) The transnational illegal wildlife trade. Criminal Justice Studies, 17, 57-73.

Waterman, C., Pietersen, D., Hywood, L., Rankin, P. \& Soewu, D. (2014a) Smutsia gigantea. The IUCN Red List of Threatened Species 2014: e.T12762A45222061 [accessed 8 January 2016].

Waterman, C., Pietersen, D., Soewu, D., Hywood, L. \& Rankin, P. (2014b) Phataginus tetradactyla. The IUCN Red List of Threatened Species 2014: e.T12766A45222929 [accessed 8 January 2016].

Waterman, C., Pietersen, D., Soewu, D., Hywood, L. \& Rankin, P. (2014c) Phataginus tricuspis. The IUCN Red List of Threatened Species 2014: e.T12767A45223135 [accessed 8 January 2016].

Wu, S., Liu, N., Zhang, Y. \& Ma, G.Z. (2004) Assessment of threatened status of Chinese pangolin (Manis pentadactyla). Chinese Journal of Applied and Environmental Biology, 10, 456-461.

Wyatт, T. (2013) Wildlife Trafficking: A Deconstruction of the Crime, the Victims, and the Offenders. Palgrave Macmillan, Basingstoke, $\mathrm{UK}$.

Zhou, Z.M., Zhou, Y., Newman, C. \& Macdonald, D.W. (2014) Scaling up pangolin protection in China. Frontiers in Ecology and the Environment, 12, 97-98.

\section{Biographical sketches}

CHRIS SHEPHERD's work is focused on wildlife trade issues, and specifically on the conservation and exploitation of pangolins. ELLEN CONNELLY is a zoologist and has worked with wildlife in Zimbabwe for more than 15 years, with a strong focus on pangolins. LISA Hyw ood has been working in conservation in Zimbabwe for more than 20 years and is an expert on pangolin conservation. PHILLIP CASSEY is a wildlife ecologist and invasive species biologist. His research interests are in the management of alien species, biosecurity risk preparedness, and transnational wildlife crime. 